\title{
Capital Structure and Corporate Performance: A Case of China
}

\author{
Zeshen Ye \\ Business School, Durham University, DurhamDH13LE, UK
}

\begin{abstract}
This research focuses on the capital structure and the corporate performance in China. This research introduces different theories of capital structure. It reviews the studies conducted in different economic entities about this topic and combine with the current research in China, which can provide the evidences for this research to give the assumptions. This research uses three models, ordinary least squares (OLS), fixed effect (FE), and generalized method of moments (GMM) to process the data and find out the relationship between the capital structure and the corporate performance in China. The results of this research show a significant negative correlation between the leverage level and the return on assets of Chinese firms. It shows the relationship between the capital structure and the corporate performance. This research explains this relationship by the characteristics of Chinese market and tries to give suggestion for practice.
\end{abstract}

Keywords: Capital Structure; Corporate Performance.

\section{Introduction}

After the introduction of the reform and opening policy in 1970 s, China has been experiencing a rapid economic growth, which made China become the second largest economic entity in the world. As a market, China has its unique characteristics, such as the special political and economic systems, which makes China different from other markets. It shows the significance to study Chinese market. Multiple studies have tried to figure out the relationship between capital structure and companies' values and performances [1]. it shows that capital structure is an important topic in financial field. This research is to find out the relationship between capital structure and companies' performance in China.

The aim of this research is the capital structure and corporate performance in Chinese market. The objectives of this research will identify two objectives. Firstly, it will try to find out the relationship between capital structure and corporate performance in China. Secondly, it will try to explain the relationship by the characteristics of Chinese market.

To reach the aim of this research, there will be mainly three steps. Firstly, this research will give a brief introduction about the capital structure theory and the current studies about China. Then, it will collect data from 2014 to 2019 which not only provides the newest data set to show the current situation of China, but also is an important time period to China's development. During this period, Chinese government announced decisions to take comprehensive measure to continue reform suggesting a new step of reforming and opening policy. Thirdly, beside using the least square method and fixed effect method to regress the model, this research will use generalized method of moments (GMM) to estimate the dynamic panel model.

\section{Literature Review}

\subsection{Capital Structure Theory}

\subsubsection{Assumptions from David Durant}

David Durant developed three theories about the cost of capital and capital structure, which could be the earliest theory in this field [2]. The Net Income Theory argued that financing by debt could bring more value to the firm, because the cost of debt is lower than the cost of equity. It only considered the cost differences between equity financing and debt financing. In this case, with 100\% debt ratio, the firm will have the lowest cost of capital and maximize its value. This theory ignores too many factors and it is not practical to keep the debt ratio at $100 \%$. Therefore, David also raised 
Net Operating Income Theory. In Net Operating Income Theory, Durant took risk of debt in consideration. Although the cost of debt is lower than the cost of equity, the risk of debt will increase the cost of capital. The high leverage ratio would increase the risk of bankruptcy and influence the confidence of investors. In this case, company cannot use capital structure to adjust the cost of capital because the risk and the benefit from debt financing will counteract each other. The firm value only depends on its operating income. The Traditional Theory is a compromise between those two theories. In this theory, there is an optimal leverage level, which can minimize the cost of capital and maximize the firm value. According to Durant's research, a firm can find a capital structure with lowest cost of capital so that it can earn most value.

\subsubsection{Modigliani and Miller Theory}

Modigliani and Miller $(1958 ; 1963)$ also provided a theory to explain the relationship between capital structure and company's value [3]. They got two propositions about that. Firstly, they argued that the total value of a firm would be not influenced by its capital structure. The second proposition is that there is a linear relation between cost of equity and capital structure. When the leverage level rises, the cost of equity will increase because the risk of equity also rises with debt ratio. After that, Modigliani and Miller modified their model and considered the tax cost in their theory. Because the debt will bring interest cost to company and the interest can deduct part of tax, the company with leverage will pay less tax than the unleveraged company. According to their studies, although the capital structure will not influence the total value of a firm, capital structure is still important to a company. Debt financing could be cheaper and could bring tax deduction, but a high debt ratio will increase the interest burden and increase risk which will influence the confidence of the investors. Those could influence the performance of a firm. Companies should find a leverage level to balance its risk and cost. However, the tax shield part of this theory is challenged by some scholars. The high debt ratio can help corporate avoid tax, but the tax shield could impact the welfare of the whole society [4]. It could become a moral problem and a corporate social responsibility problem. In this consideration, corporations could not only focus on the financial statement, and should not use the tax shield to reduce their cost.

\subsubsection{Pecking Order Theory and Trade-off Theory}

Pecking Order Theory and Trade-off Theory are the development of Modigliani and Miller's theory [5]. Targeting at maximizing firm value, those two theories tried to explain capital structure's influences to firm value. Pecking Order Theory provided an order for financing. The first choice to finance is internal financing. The internal financing mainly comes from the retained earnings. It is easy to get with a lower initial cost because the money is from companies themselves. External financing is the second choice, including issuing debt and selling equity. Debt financing will bring bankruptcy risk and always need pledge so its order is after internal financing. Equity financing is considered as a negative signal which will influence the investors' confidence so it is the last choice to finance. However, Trade-off Theory focuses on the Trade-off between the benefit and cost of debt financing. Debt can reduce the income tax because the tax is based on the earing after interest. It can also help to reduce the agency cost. But debt can bring more risk to companies. It increases the interest cost and bring bankruptcy cost. Trade-off Theory argued that a firm should find an optimal capital structure to balance the benefit and the risk from the debt financing. To evaluate those two theories, different scholars have different opinions. Some recent studies tried to test those two theories, and tried to find out the better one [6]. They drew a conclusion that Pecking Order Theory can better explain the practical situation than Trade-off Theory. However, another research showed that in different areas, the different economic backgrounds and degrees of market efficiency can influence the determining factors of capital structure [7]. Those two theories may not work in every area. In a specific economic system, firms in China may present a different result from other areas. 


\subsection{Recent Studies about Capital Structure and Corporate Performance}

A recent study focusing on French manufacturing industries, tried to find out the relationship among capital structure, equity ownership and firm performance [8]. To find out the relationship between capital structure and corporate performance, they mainly tried to test two hypothesises: franchise-value hypothesis and efficiency-risk hypothesis. They also took the equity ownership in consideration, focusing more on the agency cost hypothesis. With the quantile regression, their research found that capital structure has a positive relationship with firm's efficiency in different leverage distribution, which provided support to efficiency-risk hypothesis. It also argued that different ownership concentration would have different effect on the efficiency because of the influence from the agency cost. A high ownership concentration was always linked with a high debt ratio in capital structure. However, it showed no evidence to support the relation between ownership type and capital structure. This research showed an empirical evidence to state the relationship among capital structure, equity ownership and firm performance in French manufacturing industries.

However, when Le and Phan tried to study on this topic by the evidence from a small transition country, the result was different. Le and Phan has explained the causes of this differences [9]. They considered the market efficiency. In a small transition country, the financial system is week, so that the market information is asymmetric and the supervision is laggard. In this situation, the risk of bankruptcy is higher and is hard to predict. As a result, the benefits from debt financing could be much less than the risk of bankruptcy. It meant that a higher debt ratio will lead a higher cost of capital because the high cost of bankruptcy. In order to maximize the earnings and minimize the costings, firms in small transition country would tend to choose equity financing. This result is also consistent with other studies conducted in developing countries.

Another study conducted in Baltic corporations showed a similar result. This research collected data from 36 blue-chip company in Baltic states. The scholars considered this market as an emerging market [10]. The companies in this market preferred a conservative financing policy and a low leverage level. It proved that the investors preferred companies with strong balance sheets. The share performance was linked with the sufficiency of equity capital. After regression, the research also showed a negative relationship between capital structure and profitability. It also pointed out that the profitability of capital is not a best way to explain the behaviors of the investors in this market. It could result from the market inefficiency. Although there was a significant relationship between capital structure and profitability, capital structure cannot generate excess earnings. But the sufficiency of equity can help to create the more return. This research used an emerging market as a sample and talked more from investors side to explain this topic. It provided reference to do this research focusing on China, another emerging market.

Zeitun and Tian did research focusing on Jordan to fill the blank of this field in the Middle East [11]. With the uncertain society environment in the Middle East, the scholars considered the regional risk in this study. This study covered a longer time period from 1989 to 2003 . It chose 167 companies and created an unbalanced panel. But 47 firms of them defaulted during this time period. It also showed the uncertainty of this market. The result showed a significant negative relationship between capital structure and the corporate performance. In addition, the short-term debt ratio had a positive impact on the market performance, which is measured by Tobin's Q. With consideration on the regional risk, this research found that the regional event will have a significant impact on the capital structure and the corporate performance. The Gulf Crisis from 1990 to 1991 generated a positive influence on the corporate performance and the leverage level in Jordan. It also mentioned the outbreak of Intifada in 2000, which generated a great negative impact on the corporate performance in Jordan. This research showed that the relationship between capital structure and corporate performance could be affect by the regional environment. A stable society environment is significant to the corporate performance.

Another study considered sector dynamism as a variable [12]. This research also considered the institutional differences when discussed this topic. It compared the institutional differences between the developed countries and sub-Saharan area, which is an emerging economy. It used data from 
corporations in sub-Saharan region during 1996-1999. Based on an institutional theory, it proved that the institutional differences would bring differences to the firm performance. Sub-Saharan area had an inefficient market and expensive debt. This research found that different sectors would prefer different financing methods in this market. Under this underdeveloped financial and institutional system, the corporations suffered high agency costs. The corporations with high dynamism would always have a higher agency cost. The high dynamic sectors were also easily affected by the external shocks. Under this situation, the monitoring and market discipline cannot be generated well by institutional and individual investors. The banks would have a better monitoring effect in this market. This gap made the benefits of debt more than its costs in high dynamic sectors. The sectors with high dynamism tended to finance by debt, but the stable corporations should have more equity financing. The dynamism was a negative moderator to the relationship between the firm equity and performance in this research. The strongly positive relationship between equity and corporate performance in stable corporations became negative in sectors with high dynamism. This result showed the different institutional system could generate different relationship between the capital structure and corporate performance. The dynamism of different sectors could also have a moderating effect on this relationship.

Those recent studies showed that the relationship between capital structure and corporate performance would be different in different markets. The characteristics of the market would determine the characteristics of the capital structure in this market. The development degree of an area would have impact on the capital structure and the corporate performance. A developed region with well-developed financial system and highly efficient market, would generate a positive relationship between capital structure and corporate performance. However, in emerging markets, because of the underdeveloped market system, the high debt ratio could have a negative impact on the corporate performance. Besides, the uncertainty of institution and regional risk could also have a significant influence on the capital structure.

\subsection{Studies on China}

As the development of Chinese market, more and more scholars tied to do research on this market. There were also studies focusing on the capital structure in China [13]. Those studies can provide an overview of the Chinese market.

A recent study analyzed the stability of corporate capital structure in China [14]. By the data, this research showed the characteristics of the corporate capital structure in China. This research mainly provided four results:

1.The leverage levels of listed companies in China did not keep stable. There were periods that the capital structure showed stability, but this stability would not remain for a long time. Also, the periods of stability always occurred when the firms had a high leverage level which is above 0.4.

2.Most of listed firms in China had unstable capital structure. Those firms would find their optional leverage level at a high debt level.

3.Time was a significant factor influencing the variations of capital structure.

4. The corporate capital structure in China could be affected by macroeconomic factors.

It indicated that China needs to improve the bond market system. It pointed out that bond market in China was not highly developed. Comparing developed countries and areas, Chinese bond market was developing. The bonds in market were mainly government bonds. The total corporate bonds only occupied $9.7 \%$ of the total issued bonds.

Another study also points out the issues of Chinese bond markets [15]. One of the most significant problems was the default risk. Since 2008 financial crisis, when the government unleashed 4 trillion CNY to stimulus the economy, Chinese firms have been at a high debt level. Corporate debt to Gross Domestic Product ratio grew from $101 \%$ to $160 \%$ at the end of 2017 . There were 33.3 billion CNY corporate bonds defaulting in the first six months of 2018, which was more than total default amount 30 billion in full year of 2016. Moreover, government would involve in the major restructure cases. And banks were reluctant to pursue supervision from court, because they do not want to undertake 
the losses. This phenomenon further aggravated the problems of bonds market in China. This situation made the risk of debt more significant in China. The firms were hard to keep their capital structure stable at the high leverage level which could be the optimal capital structure for those firms. Those firms cannot maintain their capital structure because of the weakness of Chinese bonds market.

China has experienced a share splitting reform, which is a peculiar case in Chinese stock market. In order to find out the influences of this reform, scholars did research on how this policy affected the corporate capital structure in China [16]. When China began to open its capital market, China Securities Regulatory Commission divided the shares issued by Chinese listed companies into tradable shares and non-tradable shares. China used this policy to maintain its control on those companies. The non-tradable shares cannot be traded freely, and majority of shares issued by Chinese listed companies were non-tradable before the share split reform. As a result, the ownership of the listed companies would not change. This restriction strengthened the power of government, and at the same time, it held the development of marketization in China. The most significant problem from it was the conflicts between two types of shareholders. The conflicts increased the agency cost in the listed companies in China, damaging the corporate governance. The share splitting reform was to transform the non-tradable share to tradable. Loosening this restriction helped China to carry out its secondary privatization. It could help to liberalize the financial system and improve the information efficiency in Chinese capital market. This reform would also bring a great change to Chinese corporate capital structure. Zhang, Gao and Yang's research showed two major effects from the share splitting reform which would impact the interest-bearing debt ratios in Chinese companies. One of them is market expansion, which will directly influence the corporate capital structure. This reform made the non-tradable shares circulating in the share market, rising the market capacity. This effect was like the new issuance, which can dilute the shares in the market. In this case, the prices of those shares will decrease. According to market timing theory, the companies would be not willing to finance by equity and tend to finance by debt. It would directly rise the debt ratios of those companies. Another effect was about the corporate governance, which will indirectly influence the leverage level of the listed companies. The share splitting reform eliminated the conflicts between non-tradable shareholders and tradable shareholders. Before the reform, the most of shares were owned by ontradable shareholders and those shareholders were the managers of those companies. The reform unified their interests which could reduce the agency costs and improve corporate governance. This improvement can help to reduce the agency costs of debt and to improve the efficiency of debt. In this case, the company could have more capacity of debt and tend to have a high leverage level. Guo, Dai and Lien's research also studied on this topic and presented three main results [17]. Firstly, it examined the validity of Trade-off theory and pecking-order theory in Chinese capital market. Secondly, it found out that Trade-off theory can better explain Chinese market and it was more prominent after the share splitting reform. which indicated that the equity could better track the deficit than the debt in China. Thirdly, this research also showed that the adjustment of capital structure in China was more flexible after the reform. The companies in China could be easier to reach their target capital structure than before. To sum up, Chinese share splitting reform help to improve the market efficiency and corporate governance in Chinese market. It enhanced the flexibility for companies to adjust the financing choice. The reform increased the debt ratios of Chinese listed companies directly and indirectly.

There were studies focusing different industries to explain the capital structure in China. A study tried to find out the determinants of capital structure in Chinese property firms [18]. It pointed out that the property industry was unique when making capital structure decision, because they companies would have more collateral for debt and would always be at high leverage level. Property industry was important and unique to China. More than half of property firms had a great portion of state-owned shares. The state-owned companies tended to have a high leverage level, because bank would prefer to lend money to the state-owned companies. This discriminating policy provided more debt to those companies in a lower cost so they would keep a higher leverage level. Dalci's study focused on another important industry in China, finding that the relationship is an inverted U-shaped 
[19]. It explained the positive relationship by the tax shield and the negative relationship by the bankruptcy risk, financial distress and agency problem. It also pointed out the information asymmetry, caused by the characteristics of Chinese institution, which would generate a negative impact of debt on corporate profitability. Like other emerging market, China lacked of market efficiency. The bond market was weak and the property rights and legal system were incomplete. As a result, the listed companies in China suffer from information asymmetry. Those factors weakened the benefits of debt and intensified the risk from debt. From those studies, an overview of the Chinese capital structure was provided. It provided empirical evidences for this research to make hypothesis.

\subsection{Hypothesis}

$\boldsymbol{H}_{\mathbf{1}}$ : the effect of capital structure on the corporate performance in China is significant

$\boldsymbol{H}_{2}$ : there is a negative relationship between leverage level and corporate performance

\section{Research Methodology}

\subsection{Data and Variables}

The data of this research was collected from Wind database, which can provide accurate and reliable Chinese financial data. The dataset includes 3,338 Chinese A listed companies, whose shares circulate in China market and are settled in Chinese Yuan. This sample could provide information more related to Chinese share market and currency policy. The panel data will be an unbalanced panel data, because of the data missing in this data set. The time period was selected between 2014-2019. This time period not only provides the newest data, which can indicate the current situation of China, but also is an important time period to China's development. At the end of 2013, Chinese government announced decisions to take comprehensive measure to continue reform, which suggested a new step of Chinese reform and open-up policy. It took methods to relax the restrictions of economy and policy, such as, relaxing investment access. Scholars argued that this period is significant to China's development [20]. It provided new changes to China, which strengthened the degree of open in China. Moreover, this time period can show the most recent situation of China, which can provide a timely and valid result.

Table 1. List of variables

\begin{tabular}{|c|c|c|c|}
\hline Variables name & Definition & Calculation & Sign \\
\hline Return on Asset (ROA) & $\begin{array}{c}\text { The ratio of net income to total } \\
\text { asset }\end{array}$ & Total debt/Total asset & - \\
\hline Leverage ratio (LEV) & The ratio of total debt to total asset & $\begin{array}{c}\text { Ln (Total asset) } \\
\text { asset }\end{array}$ & + \\
\hline $\begin{array}{c}\text { Size of company (SIZE) } \\
\text { Liquidity of company } \\
\text { (LIQUIDITY) }\end{array}$ & $\begin{array}{c}\text { The ratio of current asset to current } \\
\text { liability }\end{array}$ & current asset/ current liability & - \\
\hline $\begin{array}{c}\text { Sales growth (GROW) } \\
\text { The annual growth rate of sales } \\
\text { (This year's sales-Last year's } \\
\text { sales)/ Last year's sales }\end{array}$ & + \\
\hline $\begin{array}{c}\text { Operating profit rate } \\
\text { (PROFITRATE) }\end{array}$ & The ratio of operating profit to sales & Operating profit/Sales & + \\
\hline Equity structure (HOLD) & $\begin{array}{c}\text { The shareholding proportion of the } \\
\text { largest shareholder }\end{array}$ & N/A & + \\
\hline
\end{tabular}

The explanatory variable in this research is the leverage level of the company $\left(L E V_{i t}\right)$, which can directly show the capital structure of the company. As for the dependent variable, this research will choose return on asset (ROA) to measure the performance of the company. It is an important indicator 
to measure the corporate performance, especially profitability. When scholars do research about profitability and corporate performance, they would choose return on asset or return on equity to measure [21]. Using return on asset can show the earnings from the total asset. Return on equity equals to return on asset multiplied by equity multiplier, which means return on equity will be influenced by the leverage level. Using return on asset can avoid this influence.

\subsection{Estimation Method}

\subsubsection{OLS Model}

In order to find out the relationship between the capital structure and cooperate performance, this research set up following formula:

$$
R O A_{i, t}=\beta L E V_{i t}+\beta X_{i t}+\varepsilon_{i t}
$$

In this model, the explanatory variable is LEV and the dependent variable is ROA. X is the vector including the control variables which are mentioned before. $\varepsilon$ is the error of the model. Time series and cross section of panel data are represented by $t$ and $i$.

To regress this model, this research used ordinary least square method (OLS) estimate the result. OLS is one of the most basic regression methods. It can provide a preliminary result and is easy to operated.

\subsubsection{Fixed Effect and Random Effect Models}

However, the OLS method ignored the heterogeneity in panel data, which can lead a biased and inconsistent result. To deal with this problem, fixed effect method and random effect method consider the individual effect which could produce a more reliable result [22].

$$
R O A_{i, t}=\beta L E V_{i t}+\beta X_{i t}+\xi_{i}+\varepsilon_{i t}
$$

Fixed effect model assumes that the individual effect $\xi_{i}$ is fixed, but random effect model assumes that is random. However, it is hard to say which one is more effective to this data set. Hausman test will be included in the result, which can help to make a selection between those two methods.

\subsubsection{Dynamic Panel Model with GMM}

Furthermore, a dynamic panel data model will be set up, which is a more advanced model providing a more consistent result.

$$
R O A_{i, t}=\alpha R O A_{i, t-1}+\beta L E V_{i t}+\sum_{k=1}^{N} \gamma_{k} x_{k i t}+\xi_{i}+\varepsilon_{i t}
$$

In this model, ROA is the return on asset, showing the corporate performance. LEV is the leverage level, showing the capital structure. $\mathrm{x}$ is the control variables. $\xi$ shows the individual effect and $\varepsilon$ is the error of the model. In this model, a lag ROA is placed on the right of the formula. It shows a dynamic change of the corporate performance, which means the data of one year will influence next year. It is more coincident to the real, and the result will be more consistent.

However, it can be noticed that, when a lag dependent variable was used to explain the dependent variable, there will generate a serious endogenous problem. Because there is a correlation between the lag variable and the disturbance, the least square method and the fixed effect model are not effective to regress the dynamic panel data model. The least square method model will be biased and inconsistent. It will produce an upper bias result. However, the estimator from fixed effect model will be lower bias, but it could be consistent when the time serious are long enough. To solve this problem, Arellano and Bond introduce the generalized method of moments (GMM) to regress the dynamic panel data model. They also provide two test Hansen test and Sargan test to deal with the overidentification problem. If the model can pass these two tests, it shows that the instrumental variables are effective and the result of regression is unbiased and consistent. Roodman arranged 
literatures and introduced the xtabond2 command in Stata [23]. This research will follow his introduction to finish the regression process via Stata using generalized method of moments.

\subsection{Regression Results}

\subsubsection{OLS Method}

After the regression, this research got the relationship between explanatory variable and dependent variable, OLS result is listed in Table 2

Table 2. LEV on ROA: OLS methods

\begin{tabular}{|c|c|}
\hline Variables & OLS \\
\hline \multirow{2}{*}{ LEV } & $\begin{array}{c}-0.7409798^{* * *} \\
(0.004261)\end{array}$ \\
\hline \multirow{2}{*}{ SIZE } & $\begin{array}{c}0.446581^{* * *} \\
(0.0010419)\end{array}$ \\
\hline \multirow{2}{*}{ GROW } & 0.0001104 \\
& $(0.0000796)$ \\
\hline \multirow{2}{*}{ LIQUIDITY } & $-0.00000147^{* *}$ \\
& $(0.000000722)$ \\
\hline \multirow{2}{*}{ POFITRATE } & $0.0081007^{* * *}$ \\
& $(0.0003484)$ \\
\hline \multirow{2}{*}{ HOLD } & $0.0008201 * * *$ \\
& $(0.0000919)$ \\
\hline \multirow{2}{*}{ Constant } & $-0.6528745^{* * *}$ \\
& $(0.00227145)$ \\
\hline Observations & 13,300 \\
\hline R2 & 0.7222 \\
\hline$* \mathrm{p}<0.1 * * \mathrm{p}<0.05^{* * *} \mathrm{p}<0.01$ & \\
\hline
\end{tabular}

\subsubsection{Fixed Effect and Random Effect Method}

Table 3. LEV on ROA: FE and RE methods

\begin{tabular}{|c|c|c|}
\hline & Model 2 & Model 2 \\
\hline Variables & FE & RE \\
\hline LEV & $-0.9266485^{* * *}$ & $(0.003918)$ \\
\hline SIZE & $(0.0040062)$ & $0.0507321 * * *$ \\
& $0.0594709 * * *$ & $(0.0013552)$ \\
\hline GROW & $(0.0031023)$ & 0.0000884 \\
& 0.0000494 & $(0.0000672)$ \\
\hline LIQUIDITY & $(0.0000651)$ & $-0.00000133 * *$ \\
& $-0.0000011^{*}$ & $(0.000000635)$ \\
\hline POFITRATE & $(0.000000652)$ & $0.0058947 * * *$ \\
& $0.0044257^{* * *}$ & $(0.000297)$ \\
\hline HOLD & $(0.0002856)$ & $0.0012349 * * *$ \\
& $0.0033788^{* * *}$ & $(0.0001176)$ \\
\hline Constant & $(0.000234)$ & $-0.7558128 * * *$ \\
\hline Observations & $-0.9831051 * * *$ & $(0.0299717)$ \\
\hline Groups & $(0.0712531)$ & 13,300 \\
\hline R2 & 13,300 & 3,338 \\
\hline
\end{tabular}

This research includes both of Fixed effect and random effect method to estimate the individual effect in this panel data. The regression result is listed in Table 3. 
Hausman (1978) provided a test to detect the endogenous regression which can help to select between fixed effect and random effect model [24]. The null hypothesis of this test is that the better model is random effect. The $p$ value of this research is less than 0.01 , which means that it can reject the null hypothesis in $1 \%$ significant level. This result shows that the fixed effect is more effective for this data set.

\subsubsection{Dynamic Panel Data with GMM}

There are mainly two types of GMM, difference GMM and system GMM. Arellano and Bond (1991) came up with the first generalized method of moments which is the difference GMM. In this estimation, it considers first difference moment condition. This difference could lead to neglect of other effects. System GMM will consider more moment conditions overcoming the weakness of difference GMM [25]. After actual regression, this research compared different results. Because of the characteristics of the data set, System GMM, which requires more conditions, cannot provide an effective result. This research will show the difference GMM result which can provide a more effective regression result from this data set.

Table 4. LEV on ROA: Dynamic Panel Data Model with GMM

\begin{tabular}{|c|c|}
\hline Variables & Coefficient \\
\hline \multirow{2}{*}{ L.ROA } & 0.2376687 \\
& $(0.1646105)$ \\
\hline \multirow{2}{*}{ LEV } & $-0.9585267 * * *$ \\
& $(0.0406133)$ \\
\hline \multirow{2}{*}{ SIZE } & $0.0988751^{* * *}$ \\
& $(0.012781)$ \\
\hline \multirow{2}{*}{ GROW } & 0.0000473 \\
& $(0.0000486)$ \\
\hline LIQUIDITY & $-0.00000131^{* * *}$ \\
& $(0.000000498)$ \\
\hline \multirow{2}{*}{ POFITRATE } & $0.0038965^{*}$ \\
& $(0.0023364)$ \\
\hline \multirow{2}{*}{ HOLD } & $0.0034796^{* * *}$ \\
& $(0.0005275)$ \\
\hline AR $(1)$ & 0.001 \\
\hline AR $(2)$ & 0.457 \\
\hline Sargan test & 0.181 \\
\hline Hansen test & 0.216 \\
\hline Time dummies are omitted. $* \mathrm{p}<0.1 * * \mathrm{p}<0.05 * * * \mathrm{p}<0.01$ & \\
\hline Wald test result is in $1 \%$ significant level & \\
\hline
\end{tabular}

\subsection{Robustness Test}

\subsubsection{Robustness of Data}

Panel data includes the time series, so the problems of time series should be solved. To guarantee the validity of the regression, the data should be stable, which means that the unit root cannot exist. To detect unit root, an ADF unit root test is included in this research. The null hypothesis of this test is that the data have unit root. The alternative hypothesis of this test is that the data have no unit root. The $\mathrm{p}$ value of this research is less than 0.01 in first difference. It rejects the null hypothesis in $1 \%$ significant level. This means this data set have no unit root in first difference, which shows the stationarity of the data. 


\subsubsection{Multicollinearity Test}

Table 5. Correlations of Independent Variables

\begin{tabular}{|c|c|c|c|c|c|c|}
\hline & LEV & SIZE & GROW & LIQUIDITY & POFITRATE & HOLD \\
\hline LEV & 1.0000 & & & & & \\
\hline SIZE & 0.2194 & 1.0000 & & & & \\
\hline GROW & 0.0155 & 0.0422 & 1.0000 & & & \\
\hline LIQUIDITY & -0.0212 & -0.0104 & 0.0017 & 1.0000 & & \\
\hline POFITRATE & -0.2187 & 0.0184 & 0.0020 & 0.0005 & 1.0000 & \\
\hline HOLD & 0.0349 & 0.1484 & -0.0053 & 0.0146 & 0.0298 & 1.0000 \\
\hline
\end{tabular}

To avoid multicollinearity problems, this research tested the correlations of independent variables. Comparing the correlations of the independent variables, it could be found that the independent variables have no a significant multicollinearity problem.

\subsubsection{Arellano-Bond Test}

To test the validity of the GMM regression, the validity of the instrument variables is important. When Arellano and Bond provided this method to estimate the dynamic panel, they also introduced different tests to examine the validity of the instrument variables [26].

Arellano-Bond test is a test to examine the autocorrelation of the disturbance term. According to Roodman the full disturbance term is autocorrelated because of the fixed effect, and it can be eliminated by GMM [27]. However, if the disturbance term has order 2 autocorrelations in differences, it will cause the invalidity of some lag instruments. By the Arellano-Bond test, it can find out whether there is autocorrelation in first order and second order differences. Table 4 provides the result of Arellano-Bond test. AR (2) represents the order 2 autocorrelation in differences. The null hypothesis of AR (2) test is that there is no autocorrelation in order 2 difference. The $p$ value is 0.457 , showing that the null hypothesis cannot be rejected. It cannot be said that there is autocorrelation in order 2 difference. The instruments will not be invalid through the autocorrelation. It does not need a more level lag in this model. this result provides more validity for this model. According to Arellano and Bond, this test has more power to test the autocorrelation than the Sargan test and Hansen test.

\subsubsection{Hansen Test and Sargan Test}

Another important test is to detect the overidentification of GMM method. Hansen test and Sargan test provide statistic to examine the overidentification of the model and the validity of the instrument variables. Although those two tests have similar function, they have their own weakness. The result of Sargan test is not robust but it will not be influenced by the number of instruments. However, Hansen test can provide a robust result. Correspondingly, the result of Hansen test could be weakened by a great number of instruments. The null hypothesis of those two tests is that the model does not have overidentification problem. Table 4 includes the results of Sargan test and Hansen test. The $p$ value is 0.181 in Sargan test and 0.216 in Hansen test. Both of those two tests show a result that it cannot reject the null hypothesis, which means that the overidentification of this model is not significant. This result can strengthen the validity of instrument variables and eliminate the concern to overidentification problem. Combining both two tests can show a robust result and it also show that the number of instruments is appropriate. 


\subsubsection{Wald Test}

Wald test provides a method to test the validity of the model by testing the coefficients of dependent variables. It can test whether the coefficients are jointly equal to zero. The null hypothesis of this test is that a set of parameters is equal to a certain value. If this model can reject the null hypothesis, the coefficients are not jointly equal to zero. It means that the dependent variables cannot be removed from this model. If the coefficients are equal to zero, it means that the independent variables can be removed without affecting the model. The $p$ value of this test in less than 0.01 . It shows that it can reject the null hypothesis of Wald test in 1\% significant level. It means that those coefficients are not jointly equal to zero. The variables cannot be removed from this model, showing the validity of the variables.

\subsection{Validity and Reliability}

This research used A-listed companies in China as object, whose shares circulate in China market and are settled in Chinese Yuan. Those companies include valid information about Chinese market. The data was collected from Wind database, which is one of the largest financial data providers in China and is always used by Chinese scholars and investors. The contents of result also showed the validity. According to the Wald test, the variables are effective and were not removed from the models.

This research has used three different models to explain the relationship between the capital structure and the corporate performance. The ordinary least squares (OLS) are the most basic models. The fixed effect (FE) and random effect (RE) models consider the individual effect in the model and this research selected the fixed effect model via the Hausman test. It shows that the fixed effect can be better to explain this relationship. This research also used generalized method of moments (GMM) to regress the dynamic penal model. It considered the effect of lagged dependent variable and solved the endogenous problem. The three models can jointly show a more robust result for this study. The imitative effect of those model was good enough. They all showed high value of R2. The coefficients of explanatory variable were all at $1 \%$ significant level. Those results can show the reliability of this research.

\section{Result, Discussion and Recommendation}

\subsection{Result and Discussion}

Table 6. LEV on ROA

\begin{tabular}{|c|c|c|c|}
\hline Variables & OLS & FE & GMM \\
\hline LEV & $\begin{array}{c}-0.7409798 * * * \\
(0.004261)\end{array}$ & $\begin{array}{c}-0.9266485^{* * * *} \\
(0.0040062)\end{array}$ & $\begin{array}{c}-0.9585267 * * * \\
(0.0406133)\end{array}$ \\
\hline SIZE & $\begin{array}{c}0.446581 * * * \\
(0.0010419)\end{array}$ & $\begin{array}{c}0.0594709 * * * \\
(0.0031023)\end{array}$ & $\begin{array}{c}0.0988751 * * * \\
(0.012781)\end{array}$ \\
\hline GROW & $\begin{array}{c}0.0001104 \\
(0.0000796)\end{array}$ & $\begin{array}{c}0.0000494 \\
(0.0000651)\end{array}$ & $\begin{array}{c}0.0000473 \\
(0.0000486)\end{array}$ \\
\hline LIQUIDITY & $\begin{array}{r}-0.00000147 * * \\
(0.000000722)\end{array}$ & $\begin{array}{c}-0.0000011^{*} \\
(0.000000652)\end{array}$ & $\begin{array}{c}-0.00000131 * * * \\
(0.000000498)\end{array}$ \\
\hline POFITRATE & $\begin{array}{c}0.0081007 * * * \\
(0.0003484)\end{array}$ & $\begin{array}{c}0.0044257 * * * \\
(0.0002856)\end{array}$ & $\begin{array}{l}0.0038965^{*} \\
(0.0023364)\end{array}$ \\
\hline HOLD & $\begin{array}{c}0.0008201 * * * \\
(0.0000919)\end{array}$ & $\begin{array}{c}0.0033788 * * * \\
(0.000234)\end{array}$ & $\begin{array}{c}0.0034796 * * * \\
(0.0005275)\end{array}$ \\
\hline
\end{tabular}

After the regressions and the tests, this research outputs a reliable and valid result. This result includes regression results from three model. 


\subsubsection{The Effect of Capital Structure on the Firm Performance is Significant}

All the three regression results show that the coefficient of leverage level is significant at $1 \%$ level. It means that the leverage level can significantly affect the return on asset in this sample. This result can prove the hypothesis 1 . It shows that the effect of capital structure on the corporate performance in China is significant. In this research, the capital structure is measured by the leverage level, which shows the debt financing situation of the firm. The performance is measured by the return on asset, which shows the return rate of total asset. It shows a consistent result with current studies, which focused on different sectors in China and showed the significant effects of capital structure on the corporate performance in this market. According to MM Theory and Trade-off Theory, this affect can be explained by the costs and benefits of the different financing sources. The direct financing cost of debt is always lower than equity financing. The debtholders bear lower risk than the shareholders. They can get fixed interest return and have priority to get payment so they are willing to get lower return. For the firms, they can get the fund from debt at lower cost. However, the margin cost of debt will increase when the leverage level rise, because the risk will also increase. Interest costs generated by debt can also influence the operation of the firm. If the firms cannot pay the interest, they will face the risk of bankruptcy. This cost will have tax deduction effect, which can deduct the cash outflow. Meanwhile, the capital structure can release signal to the investors, which will change their investment decision. This effect will also influence the financing cost. Agency cost and corporate governance are also affected by the capital structure and they are important factors to the corporate performance. The significant relationship between capital structure and corporate performance in China indicates that those effect could exist in Chinese market. The existing theory can also explain the Chinese market to some extent.

\subsubsection{Negative Relationship between Leverage Level and Corporate Performance}

The coefficients of the leverage level are $-0.7409798,-0.9266485$ and -0.9585267 in those three models. This result shows a robust negative relationship between leverage level and return on assets. It is consistent with the hypothesis 2 . The relationship between capital structure and corporate performance is negative in China. This research shows the similar result with the studies which conducted in the emerging market. In the literature review section, this research has summarized the results from those studies conducted in different markets showing that the characteristic of markets will influence this relationship. In those studies, the emerging market with immature financial and political system will lead to a negative relationship between capital structure and firm performance. The uncertainty of the market intensifies the risk of debt which strengthens the negative effects on corporate performance. Multiple studies focusing on the capital structure in China shows that the developing economic system in China has generated influences on the capital structure of Chinese firms. Those studies provided evidences to show that China is still an emerging market and shares similar characteristics with other emerging markets. In consideration of the situation in Chinese market, this negative relationship can be also explained by the characteristics of Chinese market. This research will explain this relationship from three aspects, the market efficiency, the leverage level of Chinese firms and the effect of government.

As an emerging market, Chinese market is still developing after the execution of the reform and opening policy. The market is not efficient enough, compared with the developed countries. The bond market is underdeveloped. In Chinese bond market, the government bonds occupy most proportion of total issued bonds, but the corporate bonds only occupy a small proportion in the bond market. The supervision and the transparency are weak in Chinese market because the incomplete financial and legal system. It also weakens the efficiency of Chinese market. The research showed a high default rate in Chinese bond market and the average leverage level was growing. Those issues increase the risk of Chinese bond market. The increase of risk also raises the cost of debt for the companies. In this market, it is reasonable that the correlation between leverage level and corporate performance is negative. 
The corporate capital structure in China is not stable and the leverage levels of Chinese firms stay at high level. It can be the reason of the negative correlation between leverage level and corporate performance. Study pointed out that the corporate debt in China grew at a significant speed. Corporate debt to Gross Domestic Product ratio grew from 101\% to $160 \%$ during 2017. The high leverage level and the immature bond market will increase the risk of debt. Meanwhile, studies pointed out the effects of share splitting reform on financing choice of Chinese companies. The firms tend to finance by debt after this reform because the effects of this reform on the share price and corporate governance. The non-tradable share became tradable, diluting the outstanding shares. It would lower the share price and increase the cost of equity financing. The managers are more willing to financing by debt. Therefore, the firms are hard to adjust the leverage level from high level to low. This conclusion is consistent with the Guo, Dai and Lien's research. According to the Trade-off Theory, the graph of the relationship between leverage level and corporate performance should be an inverted U shape curve. When the debt is lower than the optimal capital structure, the relationship between the debt and performance is positive because the debt can bring more benefits than its costs. However, the negative relationship in China shows that most Chinese firms have high leverage levels, which exceed the optimal capital structure. The cost and risk of debt are higher than the benefits so the marginal cost of debt is high. This situation of leverage level in Chinese firms can be an explanation for this negative relationship.

Due to Chinese political system, Chinese government has more power in the market than the western countries. Chinese government will intervene the economic activity more, and the state owns the shares of many companies. This situation will influence the corporate capital structure in China. The share splitting reform mentioned before is one of the examples that the government intervene the economic activity. The Chinese government unleashed a great number of bonds to stimulus the economy which also raised the leverage level of Chinese firms. A Research showed that the political patronage in China could influence the capital structure. The state-owned companies tend to have more long-term debt than the nonstate-owned companies. Those firms can get bank loan more easily and at lower cost. In Chinese market, state-owned companies mean low risk for the investors. Stateowned companies have more capacity of debt with the government support. Although the state-owned companies are low-risk, it does not mean state-owned companies can have good performance. Rather, the state-owned companies may have weak performance because of the corporate governance issues. In summary, the negative relationship between leverage level and corporate performance can be explained by the effect of government power.

To sum up, the result proves the hypothesises. The capital structure and corporate performance have a significant relationship in Chinese listed companies, and the leverage level have negative impact on the corporate performance. This relationship can be explained by the characteristics of the Chinese market.

\subsection{Recommendations and Practice}

\subsubsection{Recommendations for Government}

This result can provide recommendation to practice for Chinese market. The negative relationship shows the immaturity of Chinese market, especially in Chinese bonds market. To perfect the market, Chinese government should improve the market efficiency. According to the analysis of Chinese market, there are their directions that the government can improve the market. Firstly, the Chinese government should reduce the intervention in the operation of market. It should accelerate the development of market-oriented economy. Secondly, the government should improve the supervision on the listed companies. Supervision department should ensure the information disclosure, especially the debt information. Legal system should be completed to protect debtholders. It could help to reduce the risk for the investors. Thirdly, transparency of the market should be guaranteed. It can help to improve the information efficiency. In a stronger form market, the firms can adjust their capital structure to their optimal capital structure more easily. Although China is still not a well-developed market, Chinese government has been taking actions to reform the economic system. The share 
splitting reform is a good example for it. This policy eased the restriction of the share transaction, turn the non-tradable shares to tradable. It increased the liquidity of share market and improved the corporate governance of the listed companies. Although this policy raised the corporate leverage level in China, it did accelerate the privatization and marketization and improve the market efficiency in China. If Chinese government could continue the process of marketization, the Chinese market can be more efficient. According to the study mentioned before, the relationship between leverage level and corporate performance can be positive in well-developed market. It can infer that the negative relationship in China can be mitigated, or even became positive, as the development of Chinese market.

\subsubsection{Recommendations for Investors}

For the investors in Chinese, they should have a more cautious attitude when they invest or operate in Chinese market. The investors should take the corporate capital structure into consideration when making investment decision in Chinese market because the impact of capital structure on the corporate performance is significant. It would determine the return and risk of the investment. According to this research's analysis, the relationship between leverage level and firm performance is negative. The investors should be more conservative when evaluating the Chinese firm with high leverage because the firms at high leverage level always have more risk and worse performance in Chinese market. However, it does not mean that the firm with zero debt is the best. It is not practical that a firm with no debt. This research took the overall situation in China as research objective, and only found out the relationship between leverage level and firm performance controlling the other variables. In practice, the other variables will also influence the firm performance and the relationship between capital structure and firm performance could be various in different industries. The investors should take more information into account and know the overall situation of the firm when they predict the performance of the firm.

\subsubsection{Recommendations for Managers}

The managers in China should notice this relationship in Chinese market. They should pay attention to their firms' capital structure. The capital structure would be an important determinant to the performance. According to the former discussion, Chinese firms are at a relatively high leverage level. The negative relationship between leverage level and corporate performance shows that the debts of firms could exceed their optimal capital structures. Meanwhile, the firms meet the problem to lower their leverage levels, because of the market issues. The managers of Chinese firms should revaluate the firm debt situation. And they can adjust the leverage level to the optimal capital structure, according to their needs. If the adjustment is difficult for the firms with limited financing channels, they can try to take measures to hedge the risk of debt and increase the capacity of debt. It can reduce the risk and cost from the high leverage level.

\section{Conclusion}

This research has studied on the capital structure and the corporate performance in China. As the second largest economic entity, China is one of the most fast-developing countries. And China is trying to transform the form of economy form planned to market-oriented, which makes China have a unique economic system. The aim of this research was to find out the relationship between the capital structure and the corporate performance in Chinese market under this condition.

To study this topic, this research introduced different theories of capital structure. Then it reviewed the studies conducted in different economic entities about this topic and combined with the current research in China, which provided the evidences to give the assumptions. To examine the hypothesises, this research collected data from 3,338 Chinese A listed companies during the period between 2014-2019. Then this research processed the data by three models, ordinary least squares (OLS), fixed effect (FE), and generalized method of moments (GMM). This regression results showed that the relationship between leverage level and corporate performance is significantly 
negative. This result was consistent with the hypothesises. And it also showed the consistency with the other studies in this field. To explain this result, this research tried to link it with the characteristics of Chinese market. It believed that this result can be explained by the market efficiency, the leverage level of Chinese firms and the effect of government in China.

This research discussed this topic under the unique situation of Chinese market and provided an explanation to the relationship between capital structure and corporate performance in China. It proved the validity of capital structure theories and studies in China. The results of this research also provided implications for market practice. Based on the research results, this research also discussed the suggestion for the Chinese market. Those showed the significance of this research for study and practice.

\section{References}

[1] Naseem, M., Lin J., Rehman, R., Ahmad, M. and Ali, R. (2020). Does capital structure mediate the link between CEO characteristics and firm performance? Management Decision, 58(1), pp. 164-181.

[2] Durand, D. (1952). Cost of debt and equity funds for business: trends and problems of measurement. National Bureau of Economic Research, pp.215-262.

[3] Modigliani, F. and Miller, M. (1958). The Cost of Capital, Corporation Finance and the Theory of Investment. The American Economic Review, 48(3) pp.261-197.

[4] Fischer, M. and Jensen, B. (2019). The debt tax shield in general equilibrium. Journal of Banking and Finance, 100(2019), pp.151-166.

[5] Myers, S. (2001). Capital structure. Journal of Economic Perspectives,15(2), pp.81-102.

[6] Fama, E. and French, K. (2002). Testing Trade-off and pecking order predictions about dividends and debt. Review of Financial Studies, 15(1), pp.1-33.

[7] Rodrigues, S., Moura, H., Santos, D. and Sobreiro, V. (2017). Capital structure management differences in Latin American and US firms after 2008 crisis. Journal of Economics and Administrative Science, 22(42), pp.51-74.

[8] Margaritis, D. and Psillaki, M. (2009). Capital structure, equity ownership and firm performance. Journal of Banking \& Finance, 34(2010), pp.624-632.

[9] Le, T. and Phan. T. (2017). Capital structure and firm performance: Empirical evidence from a small transition country. Research in International Business and Finance, 42(2017), pp.710-726.

[10] Bistrova, J., Lace, N. and Peleckienè, V. (2011) The influence of Capital structure on Baltic corporate performance. Journal of Business Economics and Management, 12(4), pp.655-669.

[11] Zeitun, R. and Tian, G. (2007). Capital structure and corporate performance: evidence from Jordan. Australasian Accounting, Business and Finance Journal, 4(1), pp,40-60.

[12] Dankwa, J. and Julian, S. (2013). Dynamism, Capital Structure, and Performance in a Sub-Saharan Economy: Extending the Institutional Difference Hypothesis. Organization Science, 24(5), pp.1422-1438.

[13] Huang, G. and Song, F. (2006). The Determinants of Capital Structure: Evidence from China. China Economic Review, 17 (1), pp.14-36.

[14] Kyissima, K., Xue, G., Kossele, T. and Abeid, A. (2020). Analysis of capital structure stability of listed firms in China. China Finance Review International, 10(2), pp.213-228.

[15] Fung, H., Liu, Q., and Zhang, F. (2019). The development of China's bond market. The Chinese Economy, 52, pp.107-123.

[16] Zhang, H., Gao, S. and Yang, F., (2016). Impact of split share structure reform on capital structure: empirical evidence from China's listed companies. Applied Economics, 48(13), pp.1172-1181.

[17] Guo, L., Dai, Y. and Lien, D. (2016). The effects of China's split-share reform on firms' capital structure choice. Applied Economics, 48(27), pp.2530-2549.

[18] Liang, J., Li, L. and Song, H. (2014). An explanation of capital structure of China's listed property firms. Property Management, 32(1), pp.4-15.

[19] Dalci, I. (2018). Impact of financial leverage on profitability of listed manufacturing firms in China. Pacific Accounting Review, 30(4), pp.410-432. 
[20] Bao, X. (2014). Comprehensively Deepening Reform: The Key Choice Deciding Contemporary China's Future and Destination. Journal of China Executive Leadership Academy Yan'an, 7(1), pp.32-47.

[21] Mihaela, H. and Claudia, O. (2017) Does Capital Structure Influence Company Profitability? Studies in Business and Economics, 12(3), pp.50-62.

[22] Henderson, D. and Parmeter, C. (2015). Panel data. Applied Nonparametric Econometrics.

[23] Roodman, D. (2009). How to do xtabond2: An introduction to difference and system GMM in Stata. The Stata Journal, 9(1), pp.86-136.

[24] Hausman, J. (1978). Specification tests in econometrics. Econometrical, 46, pp.1251-1271.

[25] Blundell, R. and Bond, S. (1998). Initial conditions and moment restrictions in dynamic panel data models. Journal of Econometrics, 87, pp.115-143.

[26] Arellano, M. and Bond, S. (1991) Some Test of Specification for Panel Data: Monte Carlo Evidence and an Application to Employment Equations. Review of Economic Studies, 85, pp.227-297.

[27] Roodman, D. (2009). How to do xtabond2: An introduction to difference and system GMM in Stata. The Stata Journal, 9(1), pp.86-136. 